Maurer School of Law: Indiana University

Digital Repository @ Maurer Law

\title{
Unification of the Law Governing Secured Transactions: Progress and Prospects for Reform
}

Hannah Buxbaum

Indiana University Maurer School of Law, hbuxbaum@indiana.edu

Follow this and additional works at: https://www.repository.law.indiana.edu/facpub

Part of the Commercial Law Commons, International Law Commons, and the Secured Transactions Commons

\section{Recommended Citation}

Buxbaum, Hannah, "Unification of the Law Governing Secured Transactions: Progress and Prospects for Reform" (2003). Articles by Maurer Faculty. 366.

https://www.repository.law.indiana.edu/facpub/366

This Article is brought to you for free and open access by the Faculty Scholarship at Digital Repository @ Maurer Law. It has been accepted for inclusion in Articles by Maurer Faculty by an authorized administrator of Digital Repository@Maurer Law. For more information, please contactrvaughan@indiana.edu.

\section{$\Psi$}

LAW LIBRARY

INDIANA UNIVERSITY

Maurer School of Law
Bloomington 


\title{
Unification of the Law Governing Secured Transactions: Progress and Prospects for Reform
}

\author{
Hannah L. Buxbaum *
}

\section{I. - INTRODUCTION}

The $75^{\text {th }}$ anniversary of UNIDROIT's founding provides us with a happy occasion particularly coming as it does at the turn of the millennium $\mathbf{1}$ - to look both forward and back in assessing the progress of the unification movement in private law. This report undertakes that task in the specific context of the law governing security interests in personal property. ${ }^{2}$ An investigation of this area reveals both the enduring character of the questions that frame the unification process and a real change over recent decades in the climate for reform.

On the occasion of UNIDROIT'S $50^{\text {th }}$ anniversary, then-President MATTEUCCI catalogued some of the questions that had occupied the Governing Council during the initial phase of the Institute's activities. These included the relationship between substantive unification and unification of conflicts law; whether to limit unification to international transactions or to affect domestic law as well; and whether to strive for "organic unification" by beginning with general law or to focus on particular legal relations instead. 3 Today, architects of reform in the field of secured transactions continue to grapple with these questions in developing particular Conventions and model laws. At the same time, today's reformers operate within an environment that has changed significantly in recent decades.

In 1976, the year in which UNIDROIT's 50 th anniversary was celebrated, the most significant international secured transactions project on the horizon was a major report on the various national laws commissioned by the United Nations Commission on International Trade Law (UNCITRAL) with a view to recommending some form of harmonization activity. ${ }^{4}$

* Associate Professor of Law, Indiana University School of Law - Bloomington (United States of America). The author would like to thank Bruce Markell and Jay Westbrook for their comments on earlier drafts.

Reporter of the Session on "Harmonised modernisation of the law governing secured transactions: general-sectorial, global-regional" at the $75^{\text {th }}$ Anniversary Congress of the International Institute for the Unification of Private Law (UNIDROIT): "Worldwide Harmonisation of Private Law and Regional Economic Integration", held at Pontificia Università Urbaniana, Rome (Italy), 27-28 on September 27-28, 2002. This paper is an expanded version of the report delivered on that occasion.

1 At least to those on the 2001 side of the 2000-versus-2001 debate.

2 A note on terminology: this paper will use the terms "security interest" and "security right" interchangeably throughout.

3 Mario MATTEUCCI, "UNIDROIT: The First Fifty Years", Rev. dr. unif. / Unif. L. Rev., 1976-1, 15, 19.

4 The study, prepared by Professor Ulrich DROBNiG, was presented to UNCITRAL in 1977. See Report of the Secretary-General: study on security interests (ACN.9/131 and Annex), reprinted in: 8 Yearbook of the 
The completed report, however, suggested that the divergence among legal systems was then too great to permit unification in the area. ${ }^{5}$ As the report reflected, municipal laws at that time varied widely as to the most fundamental aspects of security interests: for instance, the level of formality needed to create a security interest; the recognition of a non-possessory security interest; the recognition of floating liens; the desirability of a unitary security interest over all moveable property of a debtor; the necessity of public registration of an interest to secure priority against other creditors; and the availability of meaningful enforcement rights upon default. 6 As a result, UNCITRAL concluded that unification was not at that time feasible, and postponed its work in the area of security law.

By 2001, the legal environment looked quite different. The intervening decades have seen many initiatives, including several sponsored by UNIDROIT, designed to achieve the harmonization of laws governing security rights - initiatives that have significantly enhanced both procedural cooperation and substantive harmonization in the field. Indeed, in what might be seen as a recognition of the favorable climate created by these developments, UNCITRAL in 2001 renewed its efforts in the area of security law, charging a working group with the development of an international regime for security rights in goods. ${ }^{7}$

The purpose of this report is to review developments in the field of security law, assessing the different approaches that have been used to resolve the difficulties presented by cross-border security transactions as well as the future of harmonization efforts in this area. Part II of the report addresses the commercial need for harmonization in this area, discussing both traditional conflicts analysis in the field and particular obstacles to reform. Part III outlines the specific reform initiatives that have been implemented to date, grouping them into sectoral instruments and regional instruments. Part IV then speculates as to the future of harmonization efforts in the field.

\section{II. - THE DESIRABILITY OF HARMONIZATION}

\section{A. Conflicts in cross-border security transactions}

Historically, municipal conflict-of-laws rules have been used to select the law governing security transactions. The increased volume of cross-border financing transactions, and the growing importance of security interests in those transactions, have exposed the substantial costs of reliance on such rules. 8

United Nations Commission on International Trade Law, 1977, 171. See also Ulrich DrOBNıG, "Mobiliarsicherheiten im internationalen Wirtschaftsverkehr", 38 RabelsZ, 1974, 469.

5 Report on the Thirteenth Session (1980), A35/17. See generally Spiros V. BAZINAS, "UNCITRAL'S Work in the Field of Secured Transactions", in Joseph J. Norton / Mads Andenas (eds.), Emerging Financial Markets and Secured Transactions, 1998 [hereinafter: Emerging Financial Markets], 211.

6 Report of the Secretary-General, supra note 4.

7 See Official Records of the General Assembly, Fifty-sixth session, Supplement 17 (A/56/17), para. 358.

8 See generally Roy GOODE, "Security in Cross-Border Transactions", 33 Texas International Law Journal, 1998, 47, 47-48 (outlining some specific reasons for increased dependence on security rights in international lending). 


\section{Transaction costs resulting from diversity of national laws}

Under the traditional conflicts approach, the creation, perfection and priority of a security interest in personal property are governed by the law of the collateral's location. Applying this rule to international loan transactions imposes a number of transaction costs. First, because the laws governing security vary in substance from jurisdiction to jurisdiction, international lending transactions require participants to research and comply with many different requirements. In a cross-border transaction involving collateral located in multiple jurisdictions, this task can be both complicated and expensive. Securing a loan with the equipment of a multinational manufacturing company, for instance, requires the creditor to determine and comply with relevant security rules in each country in which that company maintains operations. Second, the movement - or even potential movement - of collateral across borders imposes additional costs, as creditors concerned that collateral in which they have an interest may subsequently be moved to another country must research other potentially applicable laws. This is true even in purely domestic transactions, ${ }^{9}$ but leads to greater costs in cross-border financing (especially in situations in which the collateral in question is mobile and therefore intended to cross borders). Thus, if the company described above were a transportation company, the creditor would need to determine applicable security rules in every country to which the company's mobile equipment might be taken. For these reasons, even when the applicable law is easily identified, the need to monitor the movement of collateral and comply with multiple. systems adds transaction costs to international financing. 10 Third, the applicable law is in fact not always easily identified: differences in view as to the location of collateral, particularly intangible collateral, often complicate the conflicts analysis. ${ }^{11}$

\section{Costs resulting from the application of less modernized law}

The difficulties described above multiply when the laws applicable or potentially applicable to security interests in a cross-border transaction are not only unfamiliar to the creditor but substantively inadequate to protect its interests. A creditor considering a transaction secured by collateral in a particular country might find that the law of that jurisdiction does not validate a certain type of security interest at all (for instance, by not recognizing a non-possessory interest); or not to a sufficient extent (for instance, by not recognizing after-acquired property clauses); or that it does not provide for meaningful enforcement rights upon debtor default. Similarly, the holder of a security interest in certain collateral validly created under the laws of one jurisdiction might find that, should

9 That is, transactions in which the debtor, the creditor and the collateral are at least initially located in the same jurisdiction.

10 Some jurisdictions have adopted different conflicts rules in an attempt to mitigate this difficulty. Under revised Art. 9 of the US Uniform Commercial Code, for instance, the perfection and priority of a security interest in most personal property are now governed by the law of the debtor's location rather than that of the collateral's location (US Uniform Commercial Code Art. 9-301(1)).

11 See discussion of intangibles, infra, Part I(A)(3). 
the collateral move to another, the existing interest will not be recognized; 12 or, should the collateral become part of the debtor's bankruptcy estate while located in a particular jurisdiction, that the interest would not be recognized in the ensuing insolvency proceeding. ${ }^{13}$ in such cases, lending is expected to be substantially riskier and credit therefore more expensive. This problem is of course not confined to cross-border transactions; if the security laws of a particular country do not provide creditors with the assurance of meaningful enforcement rights and a transparent priority system, credit in that area may generally be either expensive or unavailable. As more and more financings include a cross-border component, however, and as it becomes easier and more common for collateral to move across borders, the problem has greater implications for the international lending market. 14

\section{Increased use of intangibles as collateral}

Increasingly, intangibles such as accounts receivable and indirectly-held securities form an important source of collateral for many borrowers. Determining the correct rule for the location of such property in order to identify the law governing a security interest in the collateral is not easy. In the case of accounts receivable, for instance, possible locations might include the place where the account was created, the location of the account debtor, and the location of the account payee. Identifying the location is further complicated when accounts are pooled, as a pool's component parts (that is, individual accounts receivable) may themselves be subject to the laws of a number of different jurisdictions. ${ }^{15}$ As the use of intangibles as collateral increases, the need to depart from a location-based conflicts rule becomes more pressing.

\section{B. Barriers to reform}

While international reform efforts in every area of commercial law face various obstacles, the reform of law governing secured credit encounters a number of additional barriers particular to that field.

\section{Proprietary aspects of security rights}

Security rights are in part contractual: the security agreement between debtor and creditor establishes the scope of the interest and the rights of the creditor against the debtor upon

12 Often, a country whose own laws do not validate a certain type of interest will not recognize a similar interest created in another jurisdiction. See generally Theodor J.R. SCHILLING, "Some European Decisions on Non-Possessory Security Rights in Private International Law", 34 International \& Comparative Law Quarterly, $1985,87,96-98$ (reviewing a series of European cases on this point).

13 On the effect of cross-border insolvency on security interests, see generally Ulrich DROBNIG, "Secured Credit in International Insolvency Proceedings", 33 Texas International Law Journal, 1988, 53.

14 For a general discussion of the economic consequences of undeveloped secured credit law for financial markets and economies, see Heywood W. FLEISIC, "Economic Functions of Security in a Market Economy", in Emerging Financial Markets, supra note 5, at 15; but see sources cited infra, note 91.

15 Similar problems arise in connection with the use of securities as collateral, which has been greatly facilitated by the growth in indirect rather than direct holdings. 
default. One factor that makes reform in this area of commercial law particularly challenging, however, is that in many systems a security right also has proprietary effect. The true value of a security interest lies in the rights to the collateral or its proceeds that it confers upon the holder as against third parties: rights against other creditors in the event of debtor default, and against other claimants in the event of debtor insolvency. However, the particular rules in each legal system regarding the proprietary effects of security interests necessarily reflect that system's general rules governing ownership and property rights. For that reason, harmonization might founder simply due to general differences in approach to property rights. These include some differences that affect security law directly, such as the question whether to accord proceeds the status of property, but also broader differences concerning the relationship between possession and property interests. 16

\section{Intersection with insolvency law}

When a debtor enters insolvency, applicable bankruptcy or insolvency law may interfere in a variety of ways with security rights. In many systems, the filing of a bankruptcy petition suspends the ability of a secured creditor to enforce its interest against the debtor; in addition, the bankruptcy administrator in most regimes has the power to avoid as preferential transfers some types of security rights created in the immediate pre-petition period. 17 In some systems, the process by which an insolvent company is reorganized may also affect the rights of certain secured creditors. 18 These and other points of intersection between insolvency law and the law governing secured credit outside the bankruptcy context create additional barriers to reform. ${ }^{19}$

\section{Policy issues}

The success of reform efforts in international commercial law has often been ascribed to a deliberate focus on the concrete technical and economic benefits to be achieved through such efforts, rather than on the sovereignty and domestic policies of the individual States involved. 20 In the area of secured transactions more than in other areas of commercial law,

16 See generally Roy GOODE, "Reflections on the Harmonisation of Commercial Law”, Rev. dr. unif. I Unif. L. Rev., 1991-1, 54, 61-2 (identifying different views on "the significance of possession as a determinant of property rights" as one of the major reasons for a gap between systems of property law).

17 The specific categories of transactions that may be avoided of course vary across jurisdictions. See Ian F. FLETCHER / Hamish ANDERSON, The Insolvency Issues, in Michael Bridge / Robert Stevens (eds.), CrossBorder Security and Insolvency, 2001, 257, 259-60 [hereinafter: Cross-Border Security].

18 In the United States, for example, reorganization plans involving debt restructuring can be imposed on dissenting creditors through the so-called "cram down" provisions.

19 The need to reconcile secured finance reform with insolvency law is complicated in some jurisdictions by the disparate regulation of the two systems. In the United States, for instance, security law is state law, but bankruptcy law is federal.

20 Discussing pitfalls in the process of negotiating uniform conventions, UNIDROIT's Secretary-General pointed to this distinction: "Covernmental delegations to expert committees or diplomatic Conferences still often seem to have trouble viewing issues raised in negotiating private law Conventions from a strictly economic, technical or legal perspective; instead, they perceive their own private law solutions as forming part of their 
however, issues of sovereignty remain central. Many of the rules governing the enforcement of security rights reflect deep policy interests external to the credit relationship itself. For instance, when non-consensual statutory creditors receive a preferential position over secured creditors, it is because that preference is deemed necessary to achieve a particular social goal (such as obtaining the payment of accrued wages to employees). While some of these policies may be common to many jurisdictions (permitting, for example, the creation of a lien against property for the benefit of workers who contributed materials or labor toward its improvement), others may not be (permitting, for example, the creation of a lien against certain property for the benefit of innkeepers). Moreover, the effect of debtor insolvency on security interests creates an additional layer of policy issues; under bankruptcy regimes as under secured credit regimes, the rules governing priority in the distribution of debtor assets reflect local social goals. ${ }^{21}$ The deep-seated and often divergent State policies and interests implicated in this field will therefore continue to draw issues of sovereign power into the harmonization debate. 22

\section{Possible solutions}

Relying on a network of disparate municipal choice-of-law rules to identify the law governing a secured transaction is unsatisfactory. Such rules do not eliminate the costs to creditors of researching potentially applicable secured credit laws and complying with the requirements of those laws. Moreover, the difficulty in accurately predicting the outcome of conflicts analysis, and the risk that such analysis may lead to the application of inadequate law, may adversely affect the cost and availability of credit. As the foregoing discussion suggests, however, a successful international security law regime must resolve an intricate complex of contract and property issues, and in the process must reconcile a wide range of procedural and quasi-regulatory rules. Possible solutions might draw on a number of different tools used in commercial law reform outside the security rights area.

\section{Uniform choice-of-law rules}

One solution might be to adopt uniform conflicts rules that would permit creditors unambiguously to determine whose laws would apply to the creation and enforcement of a security interest in a particular collateral. This approach would not reduce the cost

national sovereignty." Herbert KRONKE, "International uniform commercial law Conventions: advantages, disadvantages, criteria for choice", Unif. L. Rev. / Rev. dr. unif., 2000, 13, 17.

21 For a proposal regarding the treatment of local priorities in cross-border bankruptcies, see Jay Lawrence WESTBROOK, "Universal Priorities", 39 Texas International Law Journal, 1988, 27.

22 Compare Jacob S. ZIEGEL, "Harmonization of Private Laws in Federal Systems of Government: Canada, the USA, and Australia", in Ross Cranston (ed.), Making Commercial Law: Essays in Honour of Roy Goode, 1997 [hereinafter: Making Commercial Law], 132, 166, speaking of commercial law reform generally ("Topics in the international commercial area look most attractive [as potential subjects of harmonization] because all states have an interest in reducing trade barriers, and because uniform commercial laws do not ordinarily implicate cultural or political values") with Ronald C.C. CUMING, "The Internationalization of Secured Financing Law: the Spreading Influence of the Concepts UCC, Art. 9 and its Progeny", in Making Commercial Law, 499 at 499 , speaking of security law in particular (the area of secured finance "... is perceived as embodying cultural attitudes and public policy choices that vary greatly among states ..."). 
of researching and complying with the substantive laws of different jurisdictions, however. More importantly, it is debatable whether such a measure can attain the level of predictability and certainty as to priority that secured creditors desire. ${ }^{23}$ As long as some municipal systems have rules inadequate to guarantee secured status to a creditor, uniform choice-of-law rules cannot eliminate the risk that a valid security interest created in one jurisdiction will not be recognized, or that the creditor's original priority position will not be honored, in another jurisdiction to which the collateral is moved. In addition, a uniform conflicts rule would not eliminate the incongruities caused by application of laws designed for domestic use to cross-border lending transactions. For these reasons, unification of conflicts rules is generally characterized as a "second-best solution". 24

\section{Uniform standards or principles}

One reform tool that has been used successfully in other areas is the set of uniform standards or principles designed to be incorporated by participants in individual transactions. 25 Some of the observations set forth above, however, suggest that such an approach would be of limited utility in the area of security rights. Deference to party autonomy can take reform only so far in this area, as no agreement between debtor and creditor can regulate completely the operation of the resulting security right against third parties. While such an instrument might be useful in standardizing certain aspects of practice between parties to a security agreement, it would not be well suited to address the proprietary aspects of security or the deep policy issues underlying questions of priority.

\section{Harmonized substantive rules for use in international transactions}

A further strategy - again, one that has been successful in other commercial law areas is the development of an instrument applicable only to cross-border transactions. Rather than harmonizing completely the substantive law in a particular field, such a Convention would adopt a harmonized set of rules for use in international transactions alone. 26 In secured finance, however, applying different rules to domestic transactions and crossborder transactions is problematic because of the proprietary effects of security. As noted above, the real value of a security interest lies in the rights that it confers upon the holder as against third parties. In a system in which a purely domestic transaction would lead to a security interest created under one set of rules, and an international transaction would

23 See Alexander VON ZIEGLER, "Particularities of the Harmonisation and Unification of International Law of Trade and Commerce, in Jürgen Basedow et al (eds.), Private Law in the International Arena - Liber Amicorum Kurt Siehr, 2000, at 878-79; Roy GOODE, Official Commentary to the Convention on International Interests in Mobile Equipment and Protocol Thereto on Matters Specific to Aircraft Equipment (hereinafter: Official Commentary), 2002, at 8.

24 GOODE, supra note 16 , at 69.

25 Some examples include the INCOTERMS, used by parties to shipping transactions, and the Uniform Customs and Practice (UCP) used in letters of credit. See GOODE, supra note 16, at 58, discussing such non-law instruments that "depend for their effect on contractual incorporation."

26 An example is the United Nations Convention on Contracts for the International Sale of Coods (the Vienna Sales Convention - CISG), which sets forth contract rules applicable to sales of goods between parties in different member States. 
lead to a security interest created under another, there will be constant priority conflicts across the systems. 27 Thus, an instrument applicable only in cross-border transactions could not address the entire range of issues involved in international lending.

\section{Comprehensive model laws}

Another instrument used in commercial law reform is the model law. A model law aims at a more comprehensive approach to harmonization in that, if adopted, it would govern not only transactions with a cross-border element, but purely domestic transactions as well.28 Because a model law is by definition not binding, individual States may choose to adopt it, but in their implementing legislation amend specific provisions in order to retain pre-existing rules and thereby give continued effect to local policy interests. In the area of security law, the nature of the policy interests involved and the quasi-regulatory aspect of the law suggest that States would be unwilling to abandon their own policydriven rules in favor of rules that are formulated elsewhere and reflect different policy priorities. 29 The wholesale adoption of a model law that would meaningfully assist unification therefore seems unlikely.

\section{III. - PROGRESS TOWARD HARMONIZATION: SPECIFIC REFORM INITIATIVES}

Although the various obstacles to reform frustrated early attempts at unifying secured credit law on a global level, they have not blocked reform activity entirely. The past three decades have been a period of active reform, focused on particular industries and particular geographic regions. This Part will provide a brief overview of the resulting instruments.

\section{A. Sectoral initiatives}

\section{Background}

While the modernization of security law would facilitate transactions involving personal property in general, it has been perceived as particularly critical with respect to transactions involving certain discrete categories of collateral. These include mobile goods (whose movement in the ordinary course of commerce would trigger the application of multiple laws) and intangible property (whose location is difficult to determine under traditional rules). In these fields, the general economic benefits to be gained from modernization of secured transactions law are accompanied by particular benefits attributable to the class of collateral involved. Industry-specific accords have

27 This would be particularly true between secured creditors and lien creditors, whose interests would generally arise under domestic law. For a discussion of this problem in the context of accounts receivable, see Neil B. COHEN, "Harmonizing the Law Governing Secured Credit: The Next Frontier", 33 Texas International Law Journal, 1998, 173, 186.

28 Some model laws used to harmonize international commercial law do address only international transactions: see for example the UNCITRAL Model Law on Cross-Border Insolvency.

29 See discussion supra, section II.B.3. 
therefore been developed in an effort to capitalize on this additional commercial imperative. They are addressed in chronological order.

\section{Accords}

\section{a. UNIDROIT Conventions on Factoring 30 and Leasing 31 (the Ottawa Conventions) 32}

These Conventions were completed in 1988 and have been ratified or acceded to by six and nine States, respectively. They address financing arrangements with the same economic effect as secured lending. Factoring, which permits businesses to sell their receivables for cash, offers an equivalent to receivables-based borrowing; leasing, under arrangements permitting the lessor to terminate the lease, can be the functional equivalent of secured lending. While the Conventions focus mainly on the contractual aspects of factoring and leasing arrangements, 33 their innovations - including, for instance, the Factoring Convention's validation of bulk assignments of receivables and the assignment of future receivables $\mathbf{3 4}$ - have been viewed as important early steps in the direction of modern secured credit law.

\section{b. UN Convention on Assignment of Cross-Border Receivables 35}

Adopted by the General Assembly on December 12, 2001, this Convention 36 applies to both international assignments of receivables and the assignment of international receivables. Within this scope of application, it covers the outright sale of accounts receivable as well as the creation of a security interest in such receivables. 37 The Convention provides for non-possessory security interests in receivables, thereby

30 UNIDROIT Convention on International Factoring, opened for signature 28 May 1988, entered into force 1 May 1995, reprinted in 27 International Legal Materials, 1988, 943.

31 UNIDROIT Convention on International Financial Leasing, opened for signature 28 May 1988 , entered into force 1 May 1995, reprinted in 27 International Legal Materials, 1988, 931.

32 For a general discussion of the Conventions, see Ronald CUMING, "Legal Regulation of International Financial Leasing: The 1998 Ottawa Convention", 7 Arizona Journal of International \& Comparative Law, 1989, 39; Martin J. STANFORD, "International Financial Leasing: The Status of the UNIDROIT Convention and an Analysis of its Provisions", 32 UCC Law Journal, 1999, 183.

33 The Leasing Convention, for instance, adopts conflicts rules rather than substantive rules to govern the question of a lessor's priority over third parties (Art. 7(3)).

34 Factoring Convention Art. 5.

35 For a general discussion of the Convention, see Spiros V. BAZINAS, “UNCITRAL's Contribution to the Unification of Receivables Financing Law: The United Nations Convention on the Assignment of Receivables in International Trade", Unif. L. Rev. / Rev. dr. unif, 2002, 49; Harry C. SIGMAN / Edwin E. SMITH, "Toward Facilitating Cross-Border Secured Financing and Securitization: An Analysis of the United Nations Convention on the Assignment of Receivables in International Trade", 57 Business Lawyer, 2002, 727; Spiros V. BAZINAS, "Lowering the Cost of Credit: The Promise in the Future UNCITRAL Convention on the Assignment of Receivables in International Trade", 9 Tulane Journal of International \& Comparative Law, 2001, 259; Catherine WALSH, "Receivables Financing and the Conflict of Laws: The UNCITRAL Draft Convention on the Assignment of Receivables in International Trade", 106 Dickinson Law Review, 2001, 159.

36 A/RES/56/81, $56^{\text {th }}$ session.

37 Art. 2(a). 
enhancing the availability of credit for many businesses in jurisdictions whose municipal laws did not permit non-possessory interests generally. ${ }^{38}$ By validating the bulk transfer of receivables and the assignment of future receivables, 39 it also facilitates the securitization of receivables.

While the Convention adopts substantive rules applicable to contracts of assignment themselves, it establishes a conflicts rule to govern issues of priority between an assignee and other claimants with an interest in the receivable. 40 In recognizing the need for a conflicts principle not based on the location of individual accounts, the Convention represents an important additional development in intangibles-based financing.

\section{c. Cape Town Convention on International Interests in Mobile Equipment 41}

In the late 1980s, UNIDROIT initiated a project intended to create a uniform security regime for certain classes of mobile equipment. This category of collateral presented a compelling case for reform in that the collateral was by its nature intended for use in cross-border contexts and therefore created conflicts among jurisdictions; in addition, it included only high-value and individually identifiable items. The chosen structure consists of a base Convention whose text will have effect only when combined with an industry-specific Protocol. Together with the Protocol on Matters Specific to Aircraft Equipment, this Convention was opened for signature on November 16, 2001, and has been signed by over twenty countries. 42

The Convention establishes a comprehensive scheme for the regulation of secured credit in the collateral covered, providing a framework for the creation of an "international interest" in equipment rather than simply establishing rules for the recognition of security interests created under existing national law. 43 In addition to rules governing the creation of such a security interest, it establishes rules governing the enforcement rights available to creditors and priority among creditors, 44 and calls for the development of an automated

38 For a discussion of the treatment of non-possessory interests in certain jurisdictions, see generally DROBNIC, supra note 13 , at 57-60.

39 Art. 8.

40 Art. 22. The rule adopted points to the law of the assignor's location. An important benefit of this rule is its coordination with insolvency law, as the law of the assignor's location would generally govern an insolvency proceeding relating to that assignor.

41 On this Convention and the Aircraft Protocol, see generally articles collected in $A$ New International Regimen Governing the Taking of Security in High-Value Mobile Assets: The Legal and Economic Implications (Unif. L. Rev. / Rev. dr. unif., 1999); Roy GOODE, "The Cape Town Convention on International Interests in Mobile Equipment: a Driving Force for International Asset-Based Financing", Unif. L. Rev. / Rev. dr. unif., 2002, 3; Jeffrey WOOL, "The Next Generation of International Aviation Finance Law: An Overview of the Proposed UNIDROIT Convention on International Interests in Mobile Equipment as Applied to Aircraft Equipment", 20 University of Pennsylvania Journal of International Economic Law, 1999, 499.

42 See Roy GOODE, Official Commentary, supra note 23. For information on the adoption of the Convention, see www.unidroit.org.

43 Art. 2. Because the element of internationality is met by the mobile nature of the equipment alone, the transaction in question need not itself be connected with more than one State.

44 Art. 29 sets forth the basic rule of priority: a registered international interest has priority over a laterregistered international interest and over an unregistered interest. See generally Herbert KRONKE, "Neues 
international registry system for the publication of security interests. Protocols covering rail stock 45 and space equipment 46 are under consideration.

\section{d. Hague Convention on Rights in Indirectly Held Securities}

At the end of 2002, the Hague Conference published its Convention on the Law Applicable to Certain Rights in Respect of Securities Held With an Intermediary. 47 This Convention governs security interests in investment securities that are held not directly but through clearance and settlement systems or with other intermediaries. 48 It adopts a primary choice-of-law rule in favor of the law of the State whose law was chosen to govern the relevant securities account, assuming that the securities intermediary has an office in that State. 49 The Convention thereby responds to the delocalized and dematerialized nature of indirectly-held securities by adopting a rule that does not seek to define the location of the securities themselves.

Related work is underway elsewhere. UNIDROIT has on its work program the development of substantive rules governing the use of securities as collateral. 50 In the European Union, member States are in the process of implementing a new Directive on collateral arrangements involving security interests in investment securities. 51 As a group, these efforts too respond to the tremendous growth in the use of securities holdings as collateral.

internationales Mobiliarsicherungsrecht erleichtert die Finanzierung von Luft- und Raumfahrzeugen: UNIDROITKonvention in Kapstadt verabschiedet", Zeitschrift für Luft- und Weltraumrecht, 2/2002, 147; Michel DESCHAMPS, "Les règles de priorité de la Convention et du Protocole du Cap", Unif L. Rev. / Rev. dr. unif., 2002, 17.

45 See Draft Protocol on Matters specific to Railway Rolling Stock, at www.unidroit.org. See generally Howard ROSEN, "Creating an international security structure for railway rolling stock: an idea ahead of its time?", Unif L. Rev. / Rev. dr. unif., 1999, 313.

46 See Draft Protocol on Matters specific to Space Property, at www.unidroit.org. See generally Martin J. STANFORD / Alexandre DE FONTMICHEL, "Oveniew of the current situation regarding the preliminary draft Space Property Protocol and its examination by COPUOS", Unif L. Rev. / Rev. dr. unif., 2001, 60; Dara A. PANAHY / Raman MITTAL, "The prospective UNIDROIT Convention on International Interests In Mobile Equipment as applied to Space Property", Unif L. Rev. / Rev. dr. unif, 1999, 303; Paul B. LARSEN / Juergen A. HEILBOCK, "UNIDROIT Project on Security Interests: How the Project Affects Space Objects", 64 Journal of Air Law and Commerce, 1999, 703.

47 The full text of the Convention is available at www.hcch.net/e/conventions/text36e.html.

48 For a discussion of the conflicts issues that arise in connection with such transactions, see generally Christophe BERNASCONI, Report on the Law Applicable to Dispositions of Securities Held Through Indirect Holding Systems, at www.hcch.net (a preliminary report prepared in connection with the Hague project), and Richard Potok (ed.), Cross-Border Collateral: Legal Risk and the Conflict of Laws, 2000 (a comparative study of the relevant choice-of-law rules in various jurisdictions).

49 Art. 4(1).

50 Information relating to this project is available at www.unidroit.org.

51 Directive 2002/47/EC of the European Parliament and of the Council on Financial Collateral Arrangements, Official Journal of the European Communities, L 168, 27.6.2002. This Directive builds on the 1998 Directive on Settlement Finality in Payment and Securities Settlement Systems (98/26/EC, 19 May 1998). 


\section{B. Regional initiatives}

\section{Background}

Other harmonization activity in the field of security law has taken the form of regional accords. As in the case of sectoral reform, much of the impetus prompting these initiatives derives from commercial interests. When commercial activity between particular neighboring States increases, the conflicts issues created by cross-border movement of collateral within the area become more acute. 52 There is another force driving regional reform, however, and that is local economic development. 53 As the role of secured credit in assisting economic development has become more widely accepted, economic policymakers in developing regions have initiated reform activity in an attempt to build credit markets and thereby achieve their development goals. 54

\section{Accords}

\section{a. European Bank for Reconstruction and Development's Model Law}

In 1994, intending to support countries in Central and Eastern Europe in the development of modern secured transactions laws, the European Bank for Reconstruction and Development (EBRD) issued a Model Law on Secured Transactions. 55 In 1998, the bank supplemented the Model Law with the publication of a set of core principles intended to state more generally the goals of reform in the area of secured lending. 56 Together, these proposals were designed not as fully realized legal frameworks, but as statements of the most fundamental provisions necessary to permit efficient secured lending (for instance, provisions requiring the public registration of security interests; provisions creating meaningful enforcement rights available to the creditor upon debtor default). 57 The Model

52 For an area study on this point, see Ronald C.C. CUMING, "Harmonization of the Secured Financing Law of the NAFTA Partners", 39 St. Louis University Law Journal, 1995, 809, 811 (discussing economic ties among, and commercial interests shared by, NAFTA residents as playing a role in secured credit reform in that region).

53 Boris KOZOLCHYK, "Foreword, Meeting of OAS-CIDIP-VI Drafting Committee on Secured Transactions", 18 Arizona Journal of International \& Comparative Law, 2001, 321, 326 ("From an economic standpoint, it would be foolhardy, if not grossly negligent, for any nation intent on competing globally to ignore the benefits of a good secured transactions law").

54 In this regard, their views are supported by international financial institutions such as the World Bank that condition financial assistance on the achievement of such reform. See infra note 66 . For general discussions of reform in particular areas, see KOZOLCHYK, supra note 53 (Latin America); Muna NDULO, "Harmonisation of Trade Laws in the African Economic Community", 42 International \& Comparative Law Quarterly, 1999, 101 (Africa).

55 EBRD Model Law on Secured Transactions project, available at http:/www.ebrd.com/trans/ sectrans/modellaw. For a discussion of the Model Law's provisions, see generally John A. SPANOGLE, "A Functional Analysis of the EBRD Model Law on Secured Transactions", in Emerging Financial Markets and Secured Transactions, supra note 5, 157.

56 EBRD Secured Transactions project, Core Principles, available at www.ebrd.com/trans/sectrans/prin.

57 Indeed, as the drafters noted, the model law "had to be kept simple in order to be of practical use for market economies in transition", Model Law, Introduction. 
Law has influenced security law reform in a number of Eastern European and Central Asian countries. 58

\section{b. OHADA Uniform Act on Security Rights}

The Organisation pour l'Harmonisation en Afrique du droit des affaires (OHADA), whose members include sixteen African States, in 1997 adopted a Uniform Act Organizing Securities 59 that is based largely on French law. This law validates nonpossessory security interests and, while it does not seek to implement a fully modernized security law regime, otherwise encourages the adoption of a more modern system, including use of a single public registry. 60

\section{c. Organization of American States: CIDIP-VI}

In 1996, the General Assembly of the Organization of American States (OAS) convened the sixth Inter-American Conference on Private International Law (CIDIP-VI), whose agenda included the modernization of secured transactions law. The project of drafting a model law evolved out of the National Law Center for Inter-American Free Trade's successful initiative to reform Mexican secured credit law, and had as its goal the development of a single model law for adoption by the Latin American and Caribbean . countries. This law as drafted was intended to foster economic growth in Central and South America, creating a "regional credit market for the Western Hemisphere". 61 At the conclusion of the CIDIP-VI plenary Conference, held in February 2002, the Model Law was approved and submitted to OAS member countries. 62

The Model Law regulates consensual security interests in moveable property, and provides for the creation of a preferential right upon public registration of a security interest. While the Model Law does not require adopting States to replace all existing security mechanisms, such as chattel mortgages and pledges, it does require them to create a single, uniform registry system within which interests created under such

58 For a recent example, see materials relating to the new secured transactions regime adopted in Slovakia at the beginning of 2003, at http://www.ebrd.com/pubs/sectrans/new.

59 The full text is available at www.ohada.com.

60 For a brief discussion of the OHADA Treaty framework, see John D. CROTHERS, "Recent Experience in Project Finance and Privatisation in Africa: Developments in the Maghreb and West Africa", 809 Practising Law Institute - Commercial Law, 2000, 519.

61 See John M. WILSON, "Secured Financing in Latin America: Current Law and the Model InterAmerican Law on Secured Transactions", 33 UCC Law Journal, 2000, 43, 107 ("The OAS has begun to reform the current secured financing framework as the means to alleviate the credit shortage and to increase Latin America's competitive position and make it more attractive for foreign investors.").

62 Model Inter-American Law on Secured Transactions, adopted by CIDIP-VI on 8 February 2002, available at www.oas.org. (subject to style changes). See generally Boris KOZOLCHYK / John M. WILSON, "The Organization of American States: The New Model Inter-American Law on Secured Transactions", Unif L. Rev. / Rev. dr. unif., 2002, 69; see also Diego P. Fernández ARroyo / Jan KLeINHeISTerkamp, "Die VI. Interamerikanische Spezialkonferenz für Internationales Privatrecht der Organisation Amerikanischer Staaten (CIDIP VI)", IPRax, 2002/4, 340. For a transcript of the meeting at which the model law was adopted, see 18 Arizona Journal of International \& Comparative Law (2001). 
mechanisms would be recorded and accorded priority. ${ }^{63}$ The Model Law adopts a modern view of the scope of security interests, providing for interests in after-acquired property and in attributable property (proceeds), and allowing collateral to secure future advances. It also validates non-possessory security interests, permitting the use of receivables and other intangibles as collateral. As one of the architects of the Model Law describes it, the Law is in form intended to șerve as a "bridge between the most effective institutions in the common and civil law systems." 64

\section{d. Reform assistance by financial institutions}

In developing regions - although on a country-by-country basis -, various financial institutions and non-governmental organizations are also involved in the reform process. Financial institutions including the World Bank and the Asian Development Bank have assisted in the modernization of secured transactions law in both formal and informal ways. They are involved in security law reform through their related work in insolvency law systems; 65 in addition, various international lenders often seek to condition financial assistance on the existence of a legal framework for secured lending, thereby spurring domestic reform. 66

\section{e. Legal assistance initiatives}

A number of non-governmental organizations that offer technical and legal assistance in developing regions have engaged in projects related to secured finance. The National Law Center for Inter-American Free Trade is active in Latin American and Caribbean countries, 67 and the Central European and Eurasian Law Initiative (CEELI), sponsored by the American Bar Association, provides drafting assistance and legal advice to States in Central and Eastern Europe and Asia.68 The Center for the Economic Analysis of Law is also an active participant in reform efforts, assisting both financial institutions and governments in analyzing the economic impact of proposed legislative reform. 69 Similarly, the Center for Institutional Reform and the Informal Sector at the University of Maryland aids modernization efforts, providing advisory assistance relating to the updating of existing regimes as well as the technology necessary to create functional registry systems. ${ }^{70}$

63 Art. 1.

64 See KOZOLCHYK / WILSON, supra note 62, at 129.

65 See, e.g., information about the World Bank Insolvency Initiative, at www4.worldbank.org/ legal/insolvency ini.html.

66 See Roy GOODE, "The Changing Nature of Security Rights", in Emerging Financial Markets, supra note 5,1 .

67 See information at www.natlaw.com.

68 See information at www.abanet.org/ceeli.

69 See information at www.ceal.org.

70 See information at www.iris.umd.edu. 


\section{Summary}

The regional and sectoral initiatives operate quite differently. They respond to different primary goals: sectoral initiatives seek to increase the commercial efficacy of secured lending for specific commodities or industries; regional initiatives, while they seek to do the same, do so partly only as a means of achieving the end of economic development. In addition, they use different methods of harmonization. The regional initiatives take the form of comprehensive model laws which, if adopted, would simply replace existing municipal security law. The sectoral accords, conversely, take the form primarily of multilateral Conventions that would displace municipal law only in its application to particular industry segments (and sometimes only to cross-border transactions within those segments).

Viewed as a group, these initiatives suggest that there is cause for both concern and optimism in considering the future of the harmonization process. Some lessons that might be drawn from existing reform efforts are discussed hereunder.

\section{IV. - THE STATE OF THE HARMONIZATION PROCESS}

\section{A. Picture of compromise}

One lesson that emerges clearly from an overview of the initiatives developed to date is that domestic policies continue to present a substantial obstacle to reform. When reform efforts succeed, it is because the States whose laws they will displace believe the reform legislation to offer particular benefits that outweigh whatever local policies must be abandoned in the process. ${ }^{71}$ Such efforts are therefore concentrated in areas in which the anticipated benefits are most compelling: in regions where the need for modernized credit is most acute, or in sectors in which the commercial benefit to be realized by rationalizing credit seems overwhelming. ${ }^{72}$ Yet even so, the structure of the individual reform instruments and the process by which they are negotiated reveal the extent to which States resist the abandonment of domestic rules in favor of a uniform ideal. This, in turn, suggests certain limitations on the harmonization process going forward. 7 at 10 , para 38, encouraging States to recognize this balance in circumscribing local statutory preferences (" $\mathrm{To}$ avoid discouraging secured credit, the availability of which is also a societal goal, the various societal goals should be carefully weighed in deciding whether to provide a preferential claim. Preferential claims should only be provided to the extent that there is no other effective means of satisfying the underlying societal goal and the impact on the availability of low-cost credit is acceptable.").

72 See Jeffrey WOÓL, "The case for a commercial orientation to the proposed UNIDROIT Convention as applied to aircraft equipment", Unif L. Rev. / Rev. dr. unif., 1999, 289 (approving a focus on commercial rather than diplomatic objectives in the development of the Cape Town Convention). See also Herbert KRONKE, "Parteiautonomie und Prorogationsfreiheit im internationalen Mobiliarsicherungsrecht: zwei Grundprinzipien der Konvention von Kapstadt", Liber Amicorum Gerhard Kegel (2002). 


\section{Limits to regional reform}

In this area, the need to respect local interests is often reflected most clearly in the choice of reform instrument itself. In considering the possible methods of achieving regional reform, the drafters of initiatives in various areas decided that model laws were preferable because they permitted States the flexibility to preserve local policies embedded in existing law. This choice is a strategic one - intended to maximize the odds of adoption by not forcing States to relinquish existing domestic policy provisions - but it limits the capacity of those instruments, at least in the short term, to achieve full substantive uniformity. In addition, even if particular countries could be encouraged to adopt model laws in a uniform fashion, there is no guarantee that the regimes evolving in one area will be consistent with those evolving in others. Indeed, by coalescing around the elements common to a particular region (for example, rules based on French civil law principles, in African reform), regional harmonization measures may serve to cut that region off from eventual harmonization with other regions that do not share those common elements. ${ }^{73}$

\section{Limits to sectoral reform}

Sectoral reform has been achieved not through model laws but through Conventions, which in a sense are much more restrictive: because States that choose to sign must simply opt in, less possibility exists for non-uniform adoption. Here, though, deference to local norms is evident in the scope of particular instruments, which often reflect the decision of the drafters to compromise in order to maximize the odds of successful implementation. ${ }^{74}$ Sectoral Conventions are by definition limited to transactions involving certain categories of collateral. Even within the relevant industry segments, however, the Conventions are often limited in scope. Most exclude consumer transactions; 75 others, transactions involving intellectual property rights, 76 or transactions involving interests in securities. ${ }^{77}$ Some instruments separate international from purely domestic transactions, limiting their reach to the former. 78 Others govern contractual aspects of security relationships, but provide only conflicts rules with respect to third-

73 See Mario MATTEUCCI, "The Contribution of Universal and Regional Organisations to the Development of International Trade Law", 91-2, in Schmitthoff \& Simmonds (eds.), International Economic Trade Law, 1976. See also Alejandro M. GARRO, "Unification and Harmonization of Private Law in Latin America", 40 American Journal of Comparative Law, 1992, 587 (arguing that Latin American countries should join international unification efforts rather than maintain a regional approach to reform).

74 See Roy GOODE, "The Protection of Interests in Movables in Transnational Commercial Law, Unif L. Rev. / Rev. dr. unif., 1998, 453, 459-61 (discussing the need to restrict the scope of initiatives in order to achieve particular, defined objectives).

75 See, e.g., the Receivables Convention (Art. 4(4)); the Convention on International Financial Leasing (Art. 1(4)); and the Convention on International Factoring (Art. 1(2)(a)).

76 See, e.g., the debate on inclusion of intellectual property rights in the draft Space Property Protocol, discussed in STANFORD / DE FONTMICHEL, supra note 46, at 68.

77 See, e.g., the Receivables Convention (Art. 4(2)(d)).

78 The Ottawa Conventions, for instance, apply only to cross-border transactions and therefore do not disturb municipal law in its application to purely domestic transactions at all. 
party effects. ${ }^{79}$ All in all, the need to restrict the scope of such instruments' application suggests that achieving security law reform in the commercial arena through sectoral reform alone is unlikely. While individual sectors might out of commercial necessity be successfully unified through Conventions, it is unlikely that a slow accumulation of different accords would ever be able to cover the field entirely. 80 Moreover, such an approach would inevitably result in problematic overlaps among sectoral accords. 81

In addition, sectoral reform instruments contain mechanisms permitting more ad hoc balancing of local interests, in the form of public policy exceptions. 82 Some of these exceptions have been crafted so as to be as narrow as possible, in an attempt to confine their use to truly fundamental policies. The Cape Town Convention, for instance, provides that each Contracting State must identify in advance the policy interests it plans to defend. 83 Others include language encouraging implementation in only a narrow range of cases: under the Receivables Convention, for example, the public policy exception is triggered only when application of the Convention's rules would yield a result "manifestly" contrary to forum public policy. 84 Nevertheless, the application of public policy exceptions is notoriously difficult to restrain; therefore, while they are necessary, they have the effect of encouraging adherence to local policies rather than the pursuit of uniformity.

\section{B. Progress}

At one level, these indications of continued resistance to the complete modernization of law suggest that neither sectoral nor regional reform alone will achieve complete uniformity in security law. The more pertinent question today, however, is whether and in what respects these initiatives have heightened the likelihood of eventual global uniformity. Here, I believe, there is much to suggest that they have substantially improved the climate for future reform.

79 In negotiating priority rules in the Receivables Convention, for instance, no consensus could be achieved as to a substantive approach regarding the point from which priority should be measured (e.g., the time of executing the assignment contract versus the time of publicly registering a notice of assignment). The Convention therefore adopted a conflicts rule instead, supplemented with optional substantive priority rules for the consideration of States. See supra note 40.

80 See Roy GOODE, supra note 74 , at 460 , for a nice description of this possibility ("So the field of commercial property rights is carved up slice by slice like a salami, and when enough slices have been processed they can be reassembled to provide a corpus of law covering the field as a whole.").

81 Franco FERRARI, "The UNCITRAL Draft Convention on Assignment in Receivables Financing: Critical Remarks on Some Specific Issues", in Jürgen Basedow (ed.), Liber Amicorum Kurt Siehr, 2000, 179, 180, 195-96 (referring to possible lack of coordination among instruments developed in the unification process).

82 In regional reform, specific policy exceptions are less necessary, as adopting States can simply integrate existing policy provisions into the new law.

83 Art. 39 provides the mechanism for such an advance declaration. Here, as in the regional accords, one of the drafters has noted that States will simply have to choose which goal is the more important - KRONKE, supra note 44 , at 149 (each State must decide for itself which is the more important: the integrity of its obsolescent system of legal remedies, or a reduction in credit costs for its companies, better credit-rating or, perhaps, less rigorous requirements as to capital resources for credit-providing banks).

84 Receivables Convention, supra note 36, Art. 23.1. See Cuide to Enactment, UNCITRAL Yearbook XXVIII, paragraph 89 (1997). 


\section{Procedural aspects of reform}

The initiatives have drawn attention to various process issues implicated in the reform of secured finance law, and have generated experience in addressing those issues that will be valuable for future reform. One such issue involves the question of legislative competence. The international reform of law governing secured transactions is complicated by the fact that law-making authority relevant to that task rests at different levels in different countries. This is true with respect to security law as a closed system: in some federal regimes, for instance, security interests in consumer transactions are governed at the state level while interests in commercial transactions are governed at the federal level. $85 \mathrm{It}$ is also true of security law as it relates to other areas of law: in the United States, for instance, secured credit law is state law, but bankruptcy law is federal. Thus, setting aside the more substantive question of whether either security law or insolvency law could be reformed effectively independent of the other, reformers must address the procedural issues raised by the involvement of different legislative bodies. In the process of drafting the various initiatives, reformers have explored methods of dealing with this problem.

Recent reform efforts have also dealt with changes in the constituencies of commercial law reform. While individual States were historically the primary, if not the only, actors in the reform of international commercial law, today a variety of non-State entities participate in that process. Some States are now members of regional organizations with the authority to regulate issues of commerce - for instance, the European Union - or of similar organizations that lack such authority but participate in regulatory debates - for instance, NAFTA. In addition, non-governmental organizations have in recent years become much more involved in developing international accords. 86 The reform efforts described above have provided valuable experience in orchestrating the activities of these various actors, especially in situations in which a number of different organizations have overlapping mandates (for example, UNIDROIT, the Hague Conference and UNCITRAL). That experience involves both the negotiating process, in which the representation and coordination of these various entities is the primary issue, and also the process of implementing a reform instrument. The recently-concluded Cape Town Convention provides a good illustration on these points. UNIDROIT, the sponsoring organization, worked in cooperation with the International Civil Aviation Organization, the International Air Transport Association and private industry groups, in addition to member State representatives. 87 The Convention as adopted then gave regional economic integration organizations explicit power of signature and accession. 88

85 See WILSON, supra note 61, at 73 (discussing security regimes in Argentina and Brazil).

86 In some situations, non-governmental organizations bear primary responsibility for a particular initiative; consider, e.g., the Uniform Customs and Practice developed by the International Chamber of Commerce. In others, non-governmental organizations are involved in a drafting process that includes States and other government actors; for example, the organizations involved in drafting the Cape Town Convention, as discussed infra.

87 The high level of involvement of these organizations has been identified as critical to the initiative's success. For a description of this process, see Roy GOODE, "The UNIDROIT Mobile Equipment Convention", in Cross-Border Security, supra note 17, 225 at 228-29.

88

Art. 48. 
As a group, the Cape Town Convention and the other reform initiatives of the past twenty years, both sectoral and regional, have fostered the development of a procedural framework that will heighten the efficiency of future reform.

\section{Modernizing rules}

Even more importantly, the various accords have built a shared vocabulary and a shared knowledge base about the various techniques that facilitate secured lending. In doing so, they have promoted more widespread acceptance of those techniques - including nonpossessory security interests, after-acquired property clauses, the use of intangibles as collateral, and the use of public registries for notification purposes. ${ }^{89}$ It is true, of course, that there are limits to the extent to which a technique adopted in one sector or region may be transplanted to others. For'instance, although various sectoral Conventions have introduced the notion of validating non-possessory interests in countries where such interests were not previously recognized, it does not follow that resistance to such interests outside the particular sectors involved will disappear. (Indeed, even prior to these reform efforts, many systems recognized such interests in a narrow group of areas without validating them generally. ${ }^{90}$ ) It is also true that different views on the value of security interests in general will continue to inform different rules as to their scope. 91 Nevertheless, it is indisputable that the reform initiatives have already contributed to the spread of modern credit practices.

\section{Expanding the pathways of reform}

Finally, it is important to consider the ways in which continued efforts in regional and sectoral reform will affect the modes by which future global and general reform may be achieved. Harmonizing conflicts rules, for instance, has in the past been (and to some extent is still) perceived as a second-best solution. ${ }^{92}$ As regional work encourages the spread of more modernized municipal systems, however, a choice-of-law Convention might in the future be much more useful in regulating international credit transactions.

89 The convergence that exists today is of course far from complete. For instance, the fact that civil-law systems have tended to remain more debtor-friendly than their common-law counterparts suggests that convergence may not be reached on the enforcement measures - specifically, self-help remedies - available to creditors upon default. See GOODE, supra note 66 , at 4.

90 UNCITRAL Draft Legislative Cuide, Report of the Secretary-General, Addendum, ACN.9/WG.VI/SP.2/Add. 3 at 5, para. 17.

91 This is a debate that takes place also in modernized systems. For an ongoing discussion in the US literature see, for example, Alan SCHWARTZ, "Security Interests and Bankruptcy Priorities: A Review of Current Theories", 10 Journal of Legal Studies, 1981, 1; Idem, "The Continuing Puzzle of Secured Debt", 37 Vanderbilt Law Review, 1984, 1051; Lucian Arye BEBCHUK / Jesse M. FRIED, "The Uneasy Case for the Priority of Secured Claims in Bankruptcy", 105 Yale Law Journal, 1996, 857.

92 See supra, Section $\mathrm{I}(\mathrm{C})(1)$. 


\section{V. - CONCLUSION}

Today, work continues on various sectoral and regional projects; in addition, some broader reform initiatives have been proposed. The American Law Institute has approved an International Secured Transactions Project, one goal of which is the development of a model law that would govern international secured transactions "in an integrated and comprehensive fashion." 93 UNCITRAL's current project 94 is quite broad as well, as it contemplates the development of a legal regime governing both international and domestic transactions relating to goods involved in a commercial activity. 95 Such broadbased reform will not be easy. The legislative guide being prepared by UNCITRAL, 96 for instance, must be usable both in jurisdictions with modernized and in those with less modernized systems - and sizeable gaps of course remain across countries in the level of general commercial development, the sophistication of business and commercial laws, and available information technology. Such an instrument must also be responsive to differences that persist even among modern systems of secured financing, including those relating to such fundamental questions as the functional versus formal definition of a security interest, the availability of self-help repossession, the validity of unitary security interests and the treatment of title retention devices. 97 Further, its development and implementation will require the coordination and cooperation of various institutions seeking reform, and careful definition of the roles that UNIDROIT and others will play in achieving the proper balance between the modernization of secured financing and the regulatory interests of individual States. 98

In the end, though, the most important point might be the most mundane: that, due to the efforts of UNIDROIT and other organizations over the past few decades, there is reason today to look on global reform of secured finance law with optimism.

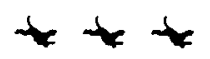

93 See Neil B. COHEN, The International Secured Transactions Project: A Proposal and Outline, SC.36 ALI-ABA, 1997, 463.

94 Supra note 7.

95 See Official Records of the Ceneral Assembly, Fifty-sixth Session, Supplement No. 17 (A/56/17). See also the report of the Secretary General on secured transactions, AVCN.9/475, 27 April 2000.

96 See Draft Legislative Guide, AVCN.9/WG.VIMP.2. and Report of Working Group VI, AVCN.9/512, 29 May 2002.

97 See generally Philip R. WOOD, “Comparative Financial Law: A Classification of the World's Jurisdictions", in Making Commercial Law, supra note 22, 31 at 42: "When one surveys the international reception of security, one is staggered by the disparities. There is not the remotest consensus."

98 This need for cooperation is of course recognized: see, e.g., the discussion in the UNCITRAL working group, noting that the Legislative Guide would not address securities (citing UNIDROIT's work in that area) or intellectual property rights (citing the need to coordinate with the World Intellectual Property Organization). AVCN.9/512, supra note 96, para. 5. 